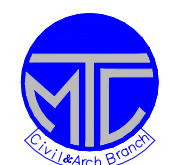

ICCAE

Military Technical College Kobry Elkobbah, Cairo, Egypt 6hㅡ International Conference on Civil \& Architecture Engineering

\title{
Effect of Blast-Furnace Slag Replacement Level on Concrete Durability
}

\author{
S.H. Okba ${ }^{1}$, E.A.Nasr ${ }^{1}$, A.S. El-Dieb ${ }^{1}$, M.R. Abd El-Megeed ${ }^{2}$ \\ ${ }^{1}$ Prof., Ain Shams University, Department of Structural Engineering, Cairo, Egypt \\ ${ }^{2}$ Associate Lecturer, Ain Shams University, Department of Structural Engineering, Cairo, \\ Egypt
}

\section{Abstract}

Composite cement is hydraulic cement composed of Portland cement and one or more inorganic materials that take part in the hydration reactions and thereby make a substantial contribution to the hydration product. The inorganic materials will be called mineral additions; other terms, such as supplementary cementing materials (SCMs), are also used. The most important are fly ash, ground granulated blastfurnace slag and silica fume. The mineral addition may be ground together with the cement clinker and gypsum, or mixed with Portland cement when the latter is used. These procedures are called intergrinding and blending respectively.

Slag can be used in conjunction with Portland cement in at least three different ways; it can be used together with limestone as a raw material for the conventional manufacture of Portland cement, or as a dry-ingredient, added to cement at the batching plants, or as a slurry added at concrete batch plant in liquid form.

The aim of this study is to investigate the effect of using different slag replacement levels on concrete durability.

KEYWORDS: Slag cement, Replacement level, Sorptivity, Absorption, Corrosion resistance, Sulphate resistance 


\section{INTRODUCTION}

Blast-furnace slag varies greatly in composition and physical structure depending on the processes used and the method of cooling of the slag [1]. For use in the manufacture of blast furnace cement the slag has to be quenched so that it solidifies as a glass and crystallization being largely prevented. This rapid cooling by water results also in a fragmentation of the material into a granulated form [2].

Blast furnace slag is formed as a liquid at $1350-1550{ }^{\circ} \mathrm{C}$ in the manufacture of iron; limestone reacts with materials rich in $\mathrm{SiO}_{2}$ and $\mathrm{Al}_{2} \mathrm{O}_{3}$ associated with the ore or present in ash from the coke. If allowed to cool slowly, it crystallizes to give a material having virtually no cementing properties. If cooled sufficiently rapidly to below $800{ }^{\circ} \mathrm{C}$, it forms a glass, which is latent hydraulic cement. Cooling is most often effected by spraying droplets of the molten slag with high-pressure jets of water. This gives a wet, sandy material which when dried and ground is called ground granulated blast furnace slag and often contains over $95 \%$ of glass [2].

The suitability of a slag for use in composite cement depends primarily on its reactivity, though grindability and content of undesirable components, especially chloride, must also be considered [2, 3]. Reactivity mainly depends on composition, glass content, fineness of grinding, and curing temperature [3, 4].

Many XRD studies have shown that the principal hydration products are essentially similar to those given by pure Portland cements, but the quantities of $\mathrm{CH}$ found are in varying degrees lower than those which would be given by the Portland cement constituent. The Portland cement components of a Portland slag cement hydrates in the normal manner and it appears that the calcium hydroxide thus liberated gives the correct alkalinity needed to provide a "starter" for the hydration of the granulated slag. However, the further hydration of the slag is direct and does not depend on combination with lime. Thus the hydration products of slag cement are similar to those of pure Portland cement pastes, apart from lower $\mathrm{CH}$ contents [2]. Also, the microstructure of paste, mortar and concrete made with slag cement is characterized by its densification and the reduction in pore size especially at the transition zone between aggregate and the bulk cement paste $[5,6]$.

The rate of hardening of Portland blast-furnace cement is slower during the first 28 days, and therefore adequate curing is of great importance; the strength requirements are therefore lower than for ordinary Portland cement [2, 4, and 7]. Figure (1) shows typical strength - time curves for OPC and Portland blast furnace slag cement.

Because of its fairly dense microstructure, reduction of pore size distribution, and low $\mathrm{C}_{3} \mathrm{~A}$ content Portland blast-furnace cement is frequently used in seawater 
construction and for improving corrosion resistance of concrete structures exposed to aggressive environments [8-11]. The relatively low energy requirement in the manufacture of Portland blast-furnace cement may be of interest in these energyconscious times, and this cement is already extensively used in many countries, which have a large production of slag. For instance, in the Netherlands, 60 per cent of all cement used is of the Portland blast-furnace type [7].

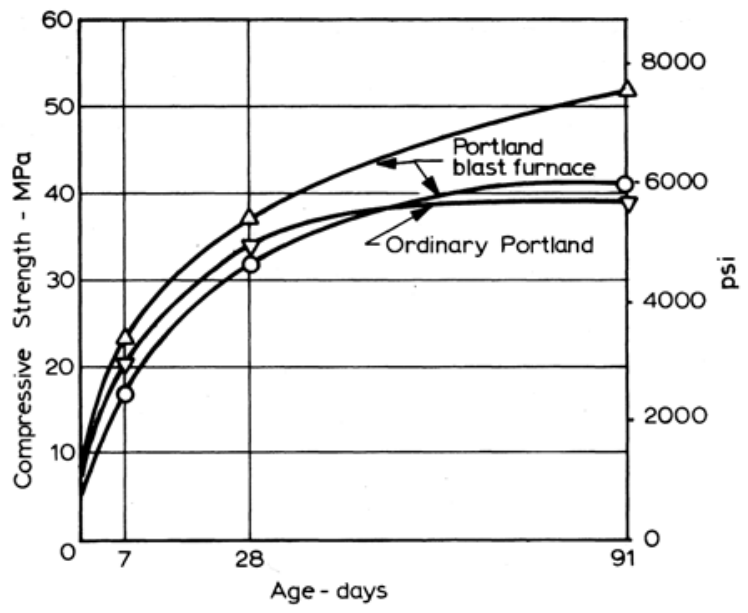

Figure 1: Strength development of concretes made with Portland blast-furnace cement (water/cement ratio $=0.6)[7]$.

\section{OBJECTIVE}

The study aims to investigate the effect of slag replacement level on concrete durability. An experimental program is designed to study the different properties of slag cement concrete. The durability and performance (mainly compressive strength, modulus of elasticity, Corrosion resistance, absorption, sorptivity, sulphate resistance and chloride diffusion) of slag cement concrete will be investigated.

\section{EXPERIMENTAL WORK}

\subsection{Materials}

Four locally available cements were used in this study. All cements satisfy the requirements of the ESS. The chemical composition is given in Table 1. The used cements were:

- Ordinary Portland cement (OPC).

- Sulfate Resistance Portland cement (SRPC).

- Slag Portland cement (SPC) (slag level 35\%).

- High Slag Portland cement (HSPC) (slag level 70\%). 
The cements were mixed together in various ratios in order to change the slag replacement level.

Table 1: Chemical composition of cements

\begin{tabular}{||lc|c|c|c|c||}
\hline \multirow{2}{*}{\multicolumn{2}{|c|}{ Property }} & \multicolumn{4}{c||}{ Percentage by Weight } \\
\cline { 3 - 6 } & & OPC & SRPC & SPC & HSRPC \\
\hline \hline Calcium oxide & $\mathrm{CaO}$ & 61.5 & 63.6 & 41.3 & 38.4 \\
\hline Silicon dioxide & $\mathrm{SiO}_{2}$ & 21.0 & 19.4 & 32.6 & 35.6 \\
\hline Aluminum oxide & $\mathrm{Al}_{2} \mathrm{O}_{3}$ & 6.1 & 4.2 & 12.7 & 14.7 \\
\hline Magnesium oxide & $\mathrm{MgO}^{2}$ & 2.4 & 1.9 & 5.2 & 6.8 \\
\hline Ferric oxide & $\mathrm{Fe}_{2} \mathrm{O}_{3}$ & 3.0 & 5.3 & 1.9 & 1.6 \\
\hline
\end{tabular}

The coarse aggregate was natural crushed stone from Attaqa quarries of nominal size of $19 \mathrm{~mm}$, a specific gravity of 2.60, absorption \% of $1.1 \%$, and Los Anglos value of $23.1 \%$. The used sand was natural siliceous sand with a specific gravity of 2.6, and fineness modulus of 2.5

\subsection{Program and Mixtures Proportions}

Eight mixes were used with $400 \mathrm{~kg} / \mathrm{m}^{3}$ cement content for each mix. The used cements were mixed in various ratios in order to have different slag level proportions. Table 2 shows the mix proportions, and the different characteristics of the mixes. The reference mixes are denoted O, F, S, HS, FS1, FS2, FHS and OHS with respect to the cement type in each mix. The experimental program is shown in Figure (2).

Table 2: Mixture proportions of concrete mixes

\begin{tabular}{|c|c|c|c|c|c|c|c|c|c|}
\hline \multicolumn{2}{|c|}{ Mix Code } & $O$ & $F$ & $S$ & $H S$ & FS1 & FS2 & FHS & $\mathrm{OHS}$ \\
\hline \multirow{4}{*}{$\begin{array}{l}\text { Cement } \\
\text { type \& } \\
\text { content } \\
\left(\mathrm{kg} / \mathrm{m}^{3}\right)\end{array}$} & OPS & 400 & 0 & 0 & 0 & 0 & 0 & 0 & 267 \\
\hline & SRPC & 0 & 400 & 0 & 0 & 200 & 133 & 267 & 0 \\
\hline & SPC & 0 & 0 & 400 & 0 & 200 & 267 & 0 & 0 \\
\hline & HSPC & 0 & 0 & 0 & 400 & 0 & 0 & 133 & 133 \\
\hline \multicolumn{2}{|c|}{ \% of Slag } & 0 & 0 & 35.0 & 75.0 & 17.5 & 23.3 & 25.0 & 25.0 \\
\hline \multicolumn{2}{|c|}{ "Sand $\left(\mathrm{kg} / \mathrm{m}^{3}\right)$} & 655 & 655 & 655 & 655 & 655 & 655 & 655 & 655 \\
\hline \multicolumn{2}{|c|}{ Crushed stone $\left(\mathrm{kg} / \mathrm{m}^{3}\right)$} & 1165 & 1165 & 1165 & 1165 & 1165 & 1165 & 1165 & 1165 \\
\hline \multicolumn{2}{|c|}{ Water $\left(\mathrm{lit} / \mathrm{m}^{3}\right)$} & 140 & 140 & 140 & 140 & 140 & 140 & 1840 & 140 \\
\hline \multicolumn{2}{|c|}{$\begin{array}{l}\text { High range water- } \\
\text { reducing }\left(\mathrm{lit} / \mathrm{m}^{3}\right)\end{array}$} & 5.0 & 5.0 & 7.2 & 8.2 & 6.4 & 6.4 & 6.4 & 6.4 \\
\hline
\end{tabular}




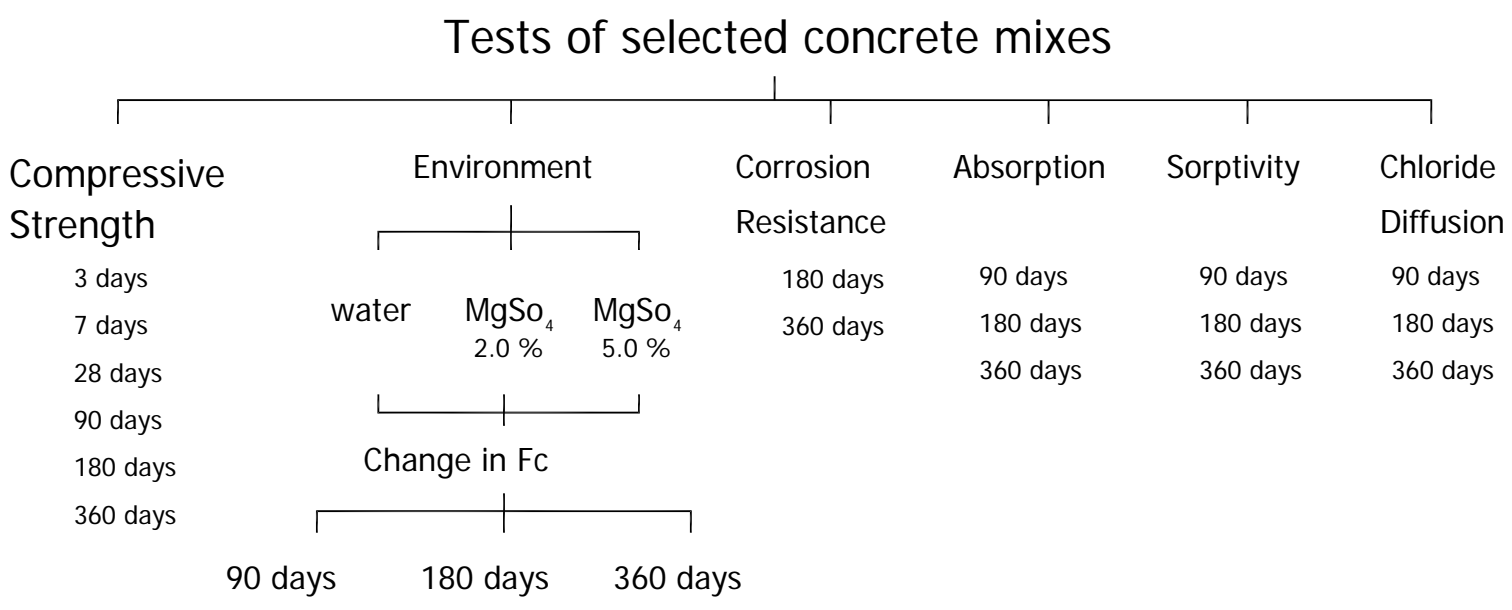

Figure 2: Experimental program of the study.

\subsection{Testing}

Six cube specimens $(158 \times 158 \times 158 \mathrm{~mm})$ were tested in compression at each test age $(3,7,28,90,180$ and 360 days).

Absorption test was carried according to ASTM C642. The specimens used for this test were concrete discs (diameter $100 \mathrm{~mm}$ and height of $50 \mathrm{~mm}$ ) cut from the middle height of the specimens cored from slabs. Three specimens were tested at each test age $(90,180$ and 360 days).

Sorptivity test was carried according to ASTM C1585. Three specimens were tested from each mixes for each test age (28, 180 and 360 days). The used specimens were concrete discs $50 \mathrm{~mm}$ height and $100 \mathrm{~mm}$ in diameter.

"Lollipop" specimens (a 100mm diameter and 200mm length concrete cylinder in which steel reinforcement bars of $10 \mathrm{~mm}$ diameter were embedded) were used to test the corrosion resistance using an accelerated corrosion cell. Testing was conducted at 180 days and 360 days of age.

Sulphate resistance test was conducted on concrete cubes $(150 \times 150 \times 150 \mathrm{~mm})$ which were immersed in a $2.0 \%$ and $5.0 \%$ of Magnesium Sulphate $\left(\mathrm{MgSO}_{4}\right)$ solution. The compressive strength loss due to sulphate attack was determined at different time intervals to examine the sulphate resistance of the concrete mixes. Six specimens were tested at 90, 180 and 360 days of immersion in the solution.

The CTH rapid method adopted by Luping [12] was used to evaluate the chloride diffusion of the concrete mixes. The test involves applying a potential of 30-40 VDC across a $50 \mathrm{~mm}$ thick specimen for a specified test duration, then splitting the specimen 
and measuring the penetration depth of chlorides by using a colorimetric method (silver nitrate becomes silver color when exposed to chloride). The experimental arrangement of the $\mathrm{CTH}$ rapid method is shown in Figure (3). The specimen is positioned at an angle in order to avoid the accumulation of small gas bubbles from the cathodic reaction. Six concrete discs of $100 \mathrm{~mm}$ in diameter and $50 \mathrm{~mm}$ in height were tested for each test age (90, 180 and 360 days).

The diffusion coefficient can be obtained by using the following equations [12]:

$$
\begin{array}{ll}
D_{n_{s s m}}=\frac{R T}{z F U} \times \frac{x_{d}-\alpha \sqrt{x_{d}}}{t} & m_{x}^{2} / s \\
\alpha=2 \sqrt{\frac{R T L}{z F U}} \times e r f^{-1}\left[1-\frac{2 c_{d}}{c_{o}}\right] &
\end{array}
$$

$\mathrm{D}_{\text {nssm }}=$ non-steady state migration diffusion coefficient $\left(\mathrm{m}^{2} / \mathrm{s}\right)$

$\mathrm{z} \quad=$ ion valence (eqiv/mol); for chloride ions $\mathrm{z}=1$

$\mathrm{F} \quad=$ Faraday's constant (96486.7 coulombs/equivalent)

$\mathrm{R}=$ gas constant $(8.3143 \times 10-3 \mathrm{~kJ} / \mathrm{Kmol})$

$\mathrm{T}=$ Absolute temperature in kelvin $(\mathrm{K})$

$\mathrm{c}(\mathrm{x}, \mathrm{t})=$ concentration of species at distance $\mathrm{x}$ and time $\mathrm{t} \quad\left(\mathrm{mol} / \mathrm{m}^{3}\right)$

$c_{o}=$ concentration of free chloride in upstream diffusion cell $\left(\mathrm{mol} / \mathrm{m}^{3}\right)$

erf $=$ error function

The specimens were tested under the following conditions:

$$
\mathrm{U}=30 \mathrm{~V} \quad \mathrm{~L}=0.05 \mathrm{~m} \quad \mathrm{~T}=298 \mathrm{~K} \quad \mathrm{t}=24 \mathrm{~h} \quad \mathrm{c}_{\mathrm{o}}=2 \mathrm{~mol} / \mathrm{l}
$$

Therefore, Equation (2) becomes:

$$
D_{n s m}=4.95 \times 10^{-13} \times\left(x_{d}-0.528 \sqrt{x_{d}}\right) \quad m_{x}^{2} / s
$$

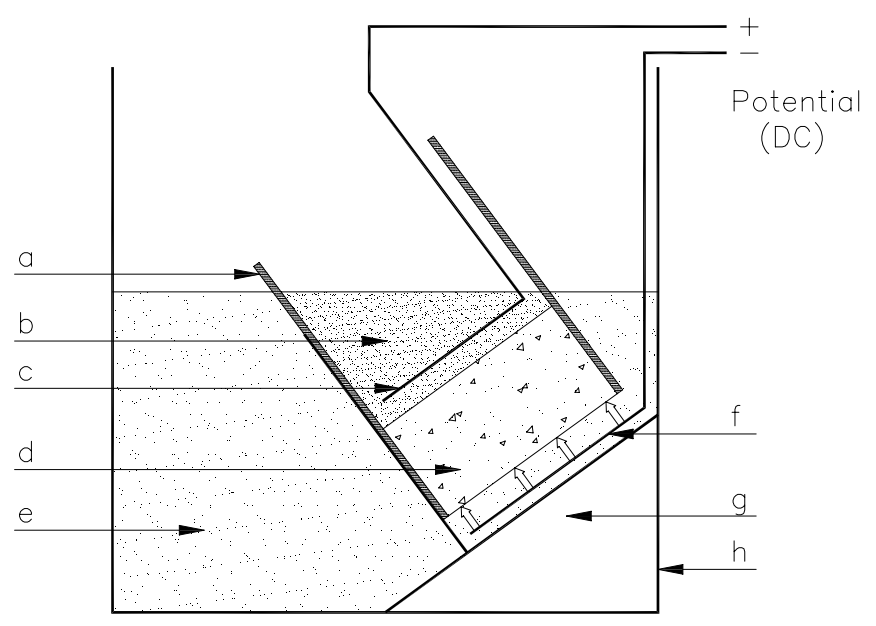

a. Rubber sleeve

b. Anolyte

c. Anode

d. Specimen

e. Catholyte

f. Cathode

g. Plastic support

h. Plastic box

Figure 3: Schematic diagram of the CTH chloride diffusion test method [12]. 


\section{TEST RESUlts AND DisCUSSIONS}

\subsection{Compressive strength}

Figure (4) shows the effect of slag replacement level on the 28days compressive strength and the percentage increase in the compressive strength at 360 days of age with respect to the 28 days.

The rate of hydration of slag cements is slower during the first 28 days; therefore the compressive strength is lower compared to the cements having no slag. As the slag replacement level increases the reduction in the 28 days strength is higher. However, at later ages - due to continuity of hydration - compressive strength of slag cement is higher, and the increase depends on the slag content.

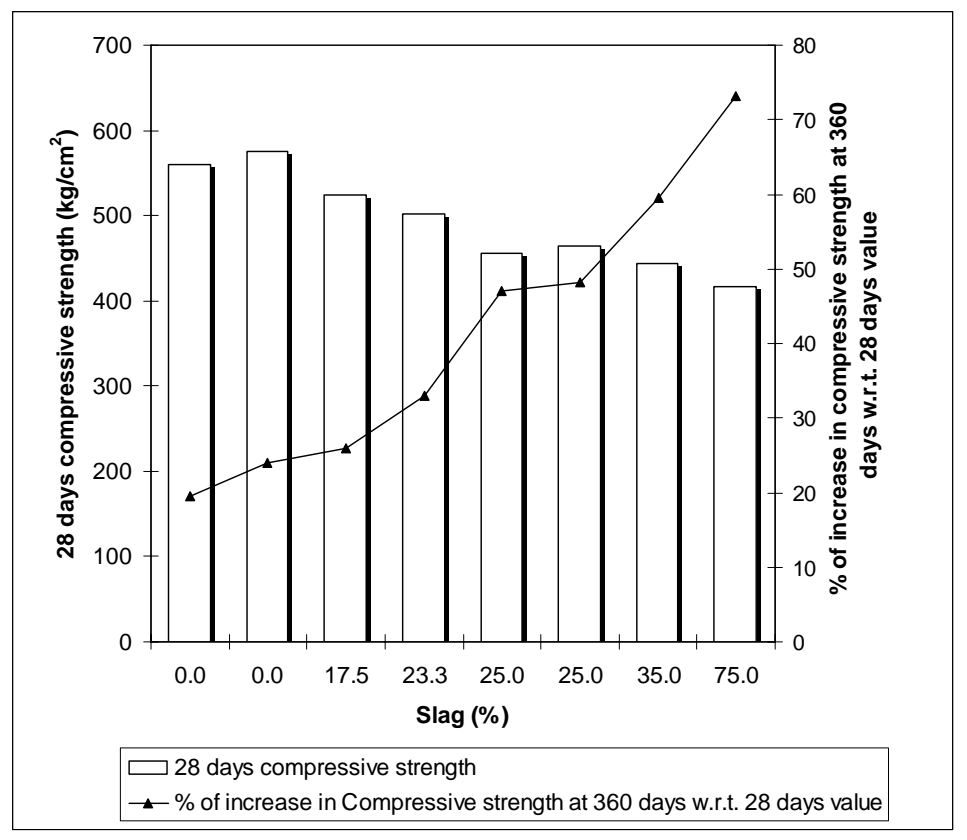

Figure 4: Effect of slag \% on 28 days compressive strength and \% increase in compressive strength at 360 days w.r.t. 28 days values.

\subsection{Absorption test}

Figure (5) shows absorption values at different test ages for the tested concrete mixes. At late age (180 and 360days) mixes incorporating slag showed higher rate of decrease in absorption values. The decrease in absorption value depends on the $\%$ of slag in the mix. It was found that, as the slag $\%$ in the mix increased the higher the reduction in absorption value with age.

Figure (6) shows the effect of slag content on the absorption \% values at 360 days and the percentage decrease in absorption values at 360 days with respect to the 90 
days value. The reduction could be attributed to the continuation of the reaction of the slag and the densification of the microstructure due to its pozzolanic effect and the refinement of the pore structure.

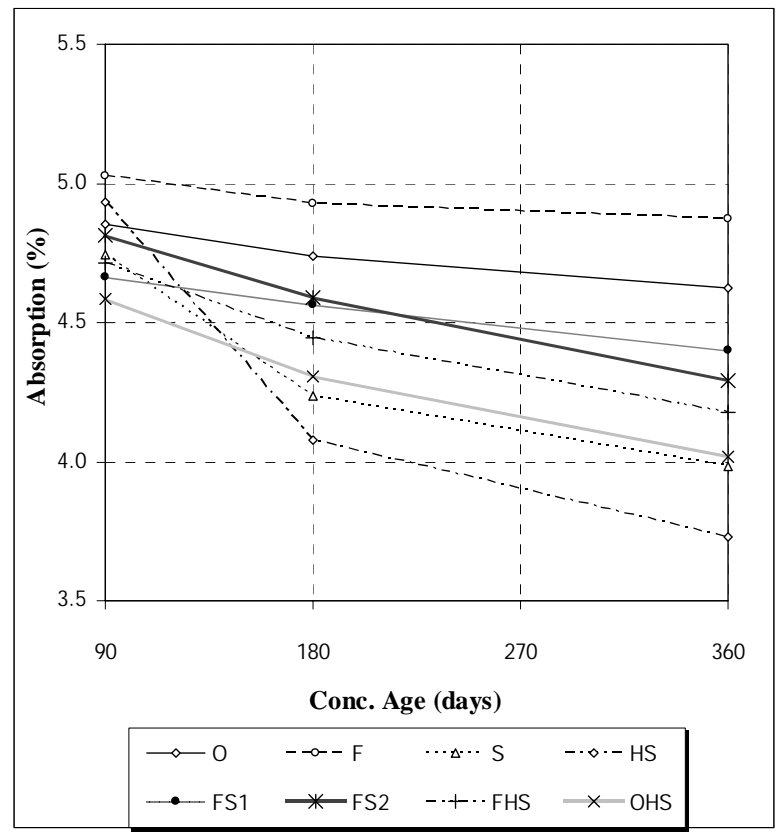

Figure 5: Absorption values at different test ages.

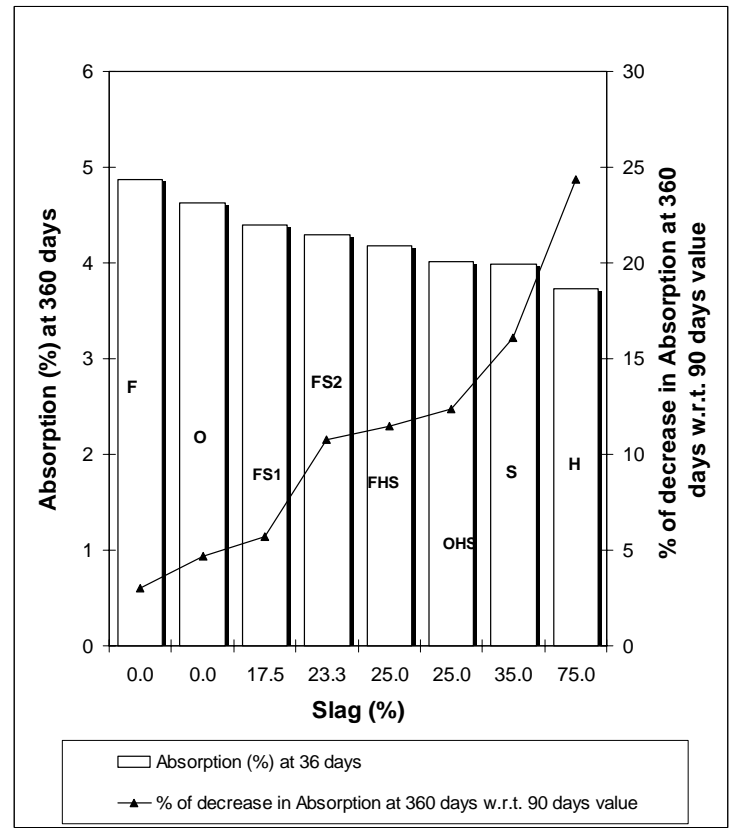

Figure 6: Effect of Slag \% on absorption values at 360 days and \% decrease in absorption values at 360 days w.r.t. 90 days values. 


\subsection{Sorptivity test}

Figure (7) shows the effect of slag replacement level on the sorptivity value (S) for different mixes concrete at 360 days of age and the percentage reduction in the sorptivity values with respect to the 90 days values.

The concrete mixes showed a behavior similar to the absorption test results. The sorptivity values showed significant reduction with age especially for the concrete mixes incorporating slag. The percentage reduction mainly depends on the slag replacement level. This is expected as sorptivity test measures the rate of capillary suction into concrete through large capillary pores, and these pores are refined and made discontinuous due to the continuation of hydration of slag and the densification of the microstructure.

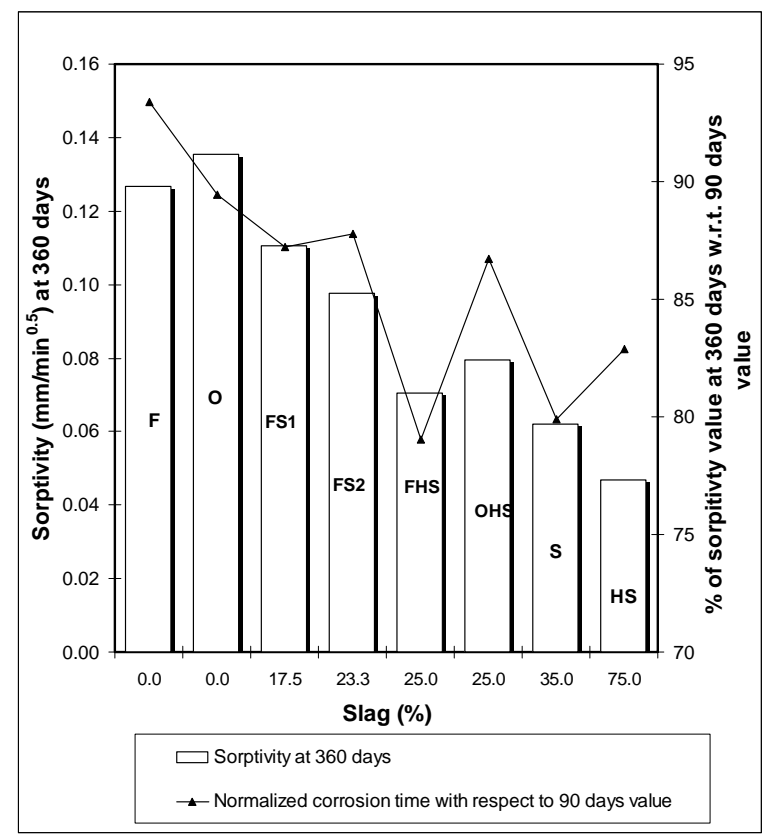

Figure 7: Effect of slag \% on sorptivity values at 360 days and \% decrease in sorptivity values at 360 days w.r.t. 90 days values.

\subsection{CTH chloride diffusion test}

Figure (8) shows the average diffusion coefficient for different concrete mixes at different ages.

Mixes incorporating slag showed higher rate of decrease in diffusion coefficient values especially at late ages. The decrease in diffusion coefficient value depends on the $\%$ of slag in the mix. It was found that, as the slag $\%$ in the mix increased the reduction in the absorption value is significant at late ages. Figure (9) shows the effect 
of slag replacement level on diffusion coefficient values and the \% decrease in diffusion values at 360 days with respect to 90 days values.

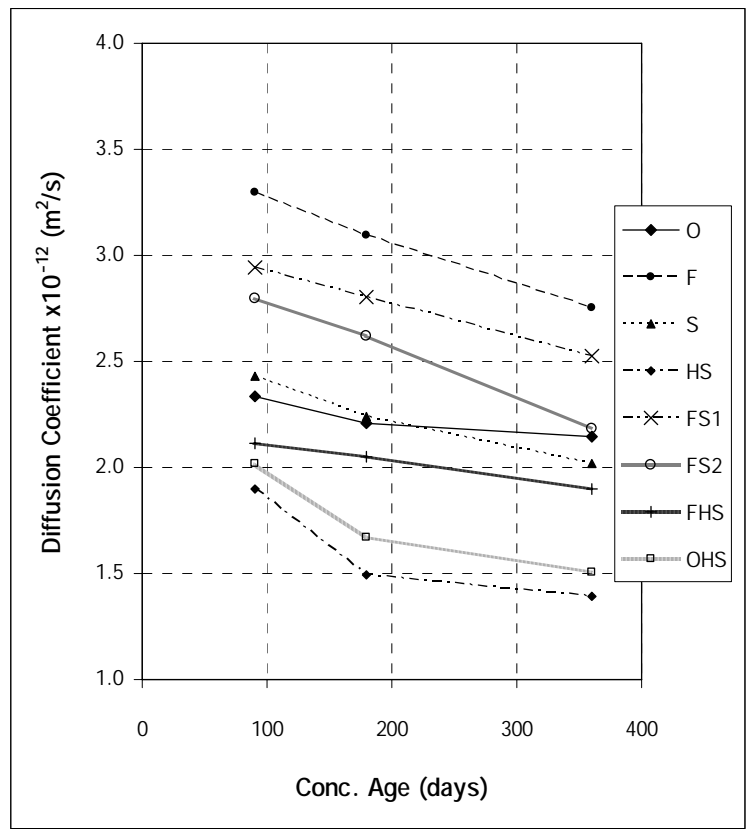

Figure 8: Diffusion coefficient for different concrete mixes at different ages.

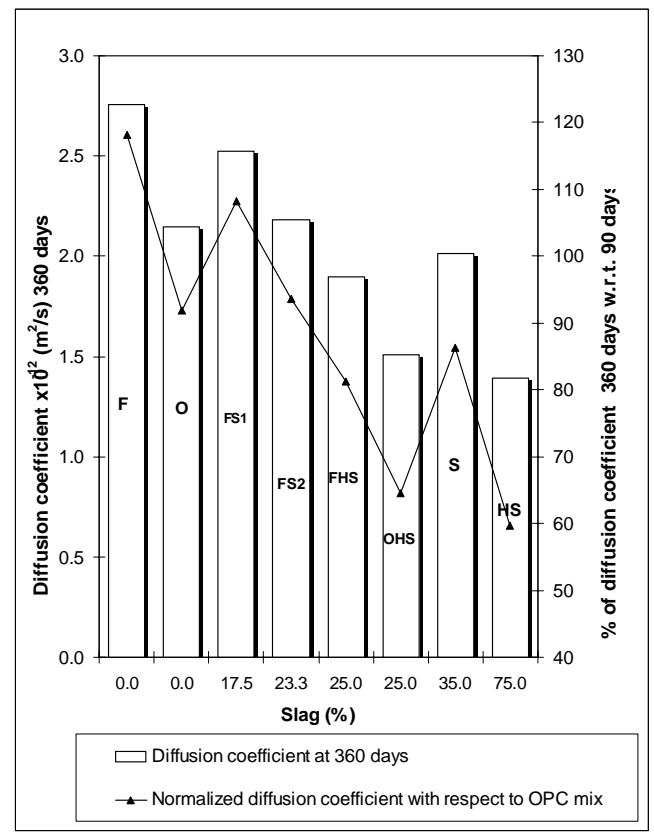

Figure 9: Effect of slag \% on diffusion coefficient values at 360 days and \% decrease in diffusion coefficient value at 360 days w.r.t. 90 days values. 


\subsection{Corrosion resistance test}

The time required to crack the specimens in the accelerated corrosion test (i.e. corrosion time) was used as a measure of the corrosion resistance of the concrete mixes. Figure (10) shows the normalized corrosion time with respect to the OPC mix at the ages (180 days and 360 days)

Concrete mixes using OPC and SRPC showed marginal increase in the corrosion resistance with respect to the other mixes containing slag, while mixes incorporating slag showed significant increase in corrosion resistance especially at late age. The increase magnitude depends on the $\%$ of slag in the mix. It was found that, as the slag $\%$ in the mix increased the improvement in corrosion resistance increased.

SRPC mix showed the lowest corrosion resistance among the test concrete mixes, this could be attributed to the low $\mathrm{C}_{3} \mathrm{~A}$ content of the cement and its effect on chloride binding and chloride induced corrosion. Although $\mathrm{C}_{3} \mathrm{~A}$ content was reduced on using slag as a replacement of the cement, the chloride induced corrosion resistance was improved; this could be associated to the pozzolanic effect of slag which improves the densification of the microstructure and refines the pore structure. The effect of slag was notable at late ages due to the continuation of the pozzolanic effect and improvement in microstructure and pore distribution.

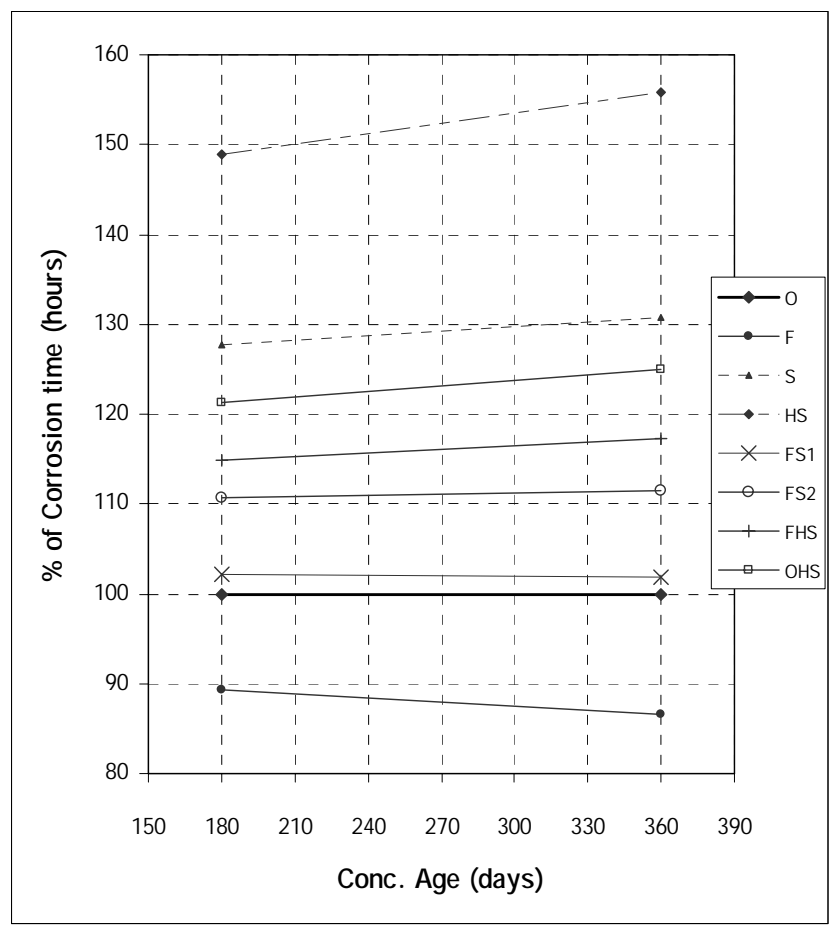

Figure 10: Normalized corrosion time with respect to OPC mix. 


\subsection{Sulphate resistance test}

Figures (11 and12) show the \% of compressive strength values after immersion in $\mathrm{MgSO}_{4}$ solution with respect to those for water exposed specimens for different concrete mixes immersed in $2 \%$ and $5 \% \mathrm{MgSO}_{4}$ solutions respectively.

It could be seen from test results that, the reduction in compressive strength increase with immersion period in the sulphate solution. The reduction in strength is higher when the concrete mixes are exposed to $5 \% \mathrm{MgSO}_{4}$ than the $2 \% \mathrm{MgSO}_{4}$ solution. Also, the increase in slag replacement level improved the resistance of concrete to the sulphate attack.

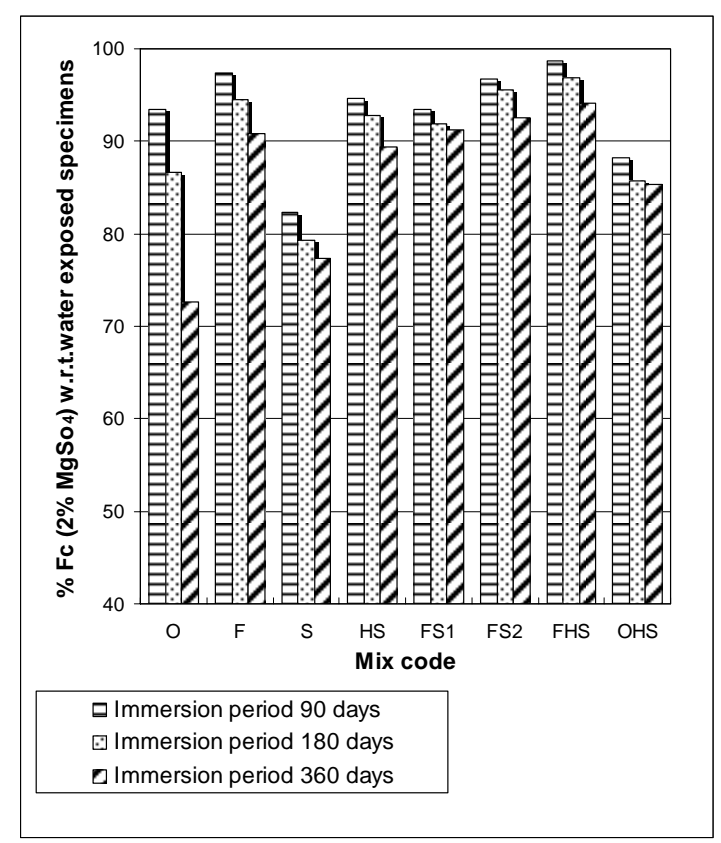

Figure 11: \% of compressive strength with time with respect to water exposed specimens for different concrete mixes immersed in $2 \% \mathrm{MgSO}_{4}$.

\section{CONCLUSiOnS}

- $\quad$ Slag cement is recommended to be used in structure where durability is the main concern since using slag improved corrosion resistance, sulphate resistance, water penetration resistance and chloride diffusion. The improvement depends on the cement type and the slag level.

- Concrete mixes using SRPC and slag showed marginal increase in chloride induced corrosion resistance with respect to the other mixes. 


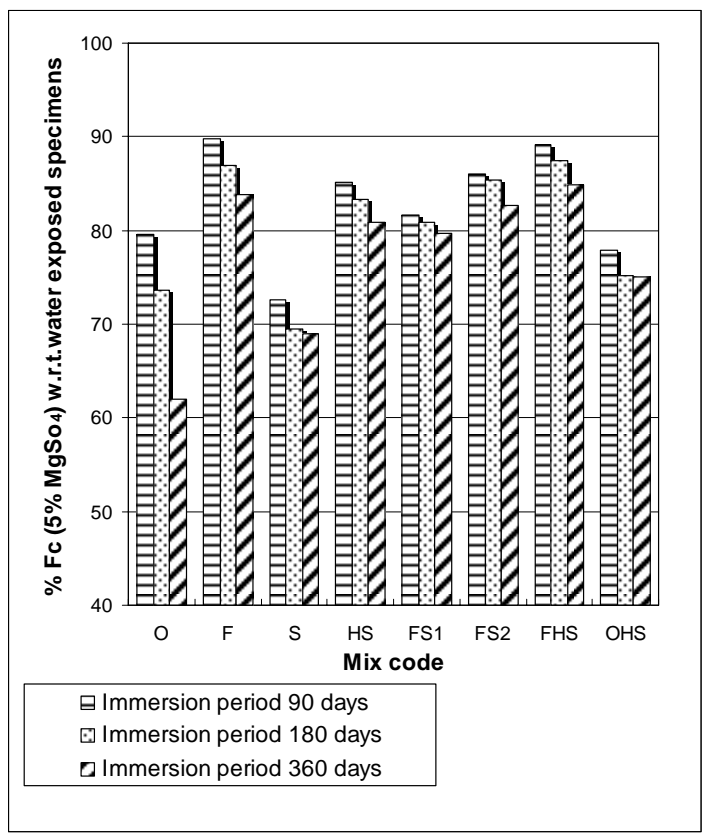

Figure 12: \% of compressive strength with time with respect to water exposed specimens for different concrete mixes immersed in $5 \% \mathrm{MgSO}_{4}$.

- $\quad$ Concrete mixes using SRPC and slag showed better sulphate resistance.

- The effect of slag was notable at late ages due to the continuation of the pozzolanic effect and improvement in microstructure and reduction of pore size.

- Incorporation of slag with any level requires great attention to curing owing to the slower rate of hydration, and this care is more significant with high slag levels.

- $\quad$ Composite cements such as slag and high slag cement (locally produced) are suitable for concrete in aggressive environments.

- $\quad$ Different slag \% could be used for different exposure conditions as follow:

Mild exposure

Moderate exposure (including moderate sulphates)

Severe exposure (including sea water)
$0 \%$ slag

$0-35 \%$ slag

$35-75 \%$ slag 


\section{REFERENCES}

1. Heikal, M., Morsy, M.S., and Radwan, M.M., "Electrical conductivity and phase composition of calcium aluminate cement containing air-cooled and water-cooled slag at 20, 40 and $60^{\circ} \mathrm{C}$ ', Cement and Concrete Research, 35:1438-1446, 2005.

2. Taylor, H.F.W, “Cement Chemistry”, Academic Press, London, 1997.

3. Öner, M., Erdoğdu, K., and Günlü, A., "Effect of components fineness on strength of blast furnace slag cement", Cement and Concrete Research, 33:463469, 2003.

4. Barnett, S.J., Soutsos, M.N., Millard, S.G., and Bungey, J.H., "Strength development of mortars containing ground granulated blast-furnace slag: Effect of curing temperature and determination of apparent activation energies", Cement and Concrete Research, 36:434-440, 2006.

5. Gao, J.M., Qian, C.X., Liu, H.F., Wang, B., and Li, L., "ITZ microstructure of concrete containing GGBS", Cement and Concrete Research, 35:1299-1304, 2005.

6. Roy, D.M., and Parker K.M., "Microstructures and properties of granulated slag-Portland cement blends at normal and elevated temperatures", Fly Ash, Silica Fume, Slag and Other Mineral By-Products in Concrete, V.M. Malhotra, Ed., SP-79, American Concrete Institute, Detroit, 1983.

7. Neville, A.M., "Properties of concrete", Forth Edition, Longman, England, 1998.

8. Abd El-Aziz, M., Abd El-Aleem. S., Heikal, M., and El-Didamony, H., "Hydration and durability of sulphate-resisting and slag cement blends in Caron's Lake water", Cement and Concrete Research, 35:1592-1600, 2005.

9. Hekal, E.E., Kishar, E., and Mostafa, H., "Magnesium sulfate attack on hardened blended cement pastes under different circumstances", Cement and Concrete Research, 32:1421-1427, 2002.

10. Yeau, K.Y., and Kim, E.K., "An experimental study on corrosion resistance of concrete with ground granulate blast-furnace slag" Cement and Concrete Research, 35:1391-1399, 2005.

11. Hou, W.M., Chang, P.K., and Hwang, C.L., "A study on anticorrosion effect of high-performance concrete by the pozzolanic reaction of slag", Cement and Concrete Research, 34:615-622, 2004.

12. Luping, T., "Chloride Transport in Concrete - Measurement and Prediction", Publication P-96:6 Chalmers University of Technology, Göteborg, Sweden, 1996 